\title{
Model Peningkatan Pemahaman Literasi Media Sosial di Kabupaten Sleman
}

\author{
Popi Andiyansari \\ Prodi Ilmu Komunikasi, Universitas Teknologi Yogyakarta \\ popi.andiyansari@gmail.com
}

\begin{abstract}
Social media is currenly one of the most used communication media by the community. The number of users of social media is not balanced with an understanding of ethics, danger, and how to counter information wisey. The ITE Law has been implemented since 2012 but does not increase the understanding and limits of users in social media. This study aims to improve public understanding of social media literacy and be able to control potentially unlawful interactions. The research method uses a quantitative approach by measuring the level of understanding of media literacy done twice, namely at the beginning of the study and the end of the study. This research is combine with treatment in the form of: socialization an practical guidance on ethics on social media. The result of this study are in the form of signifivantly increasing understanding of media literacy. The result were also obtained, the respondents did not understand the ethics and laws governing the use of social media.
\end{abstract}

Keywords: Media Literacy, Social Media Literacy, Social Media

\begin{abstract}
Abstrak
Media sosial saat ini menjadi salah satu media komunikasi yang paling digunakan masyarakat. Banyaknya pengguna media sosial ini tidak diimbangi dengan pemahaman atas etika, bahaya, dan cara meng-counter informasi dengan bijaksana. UU ITE telah diberlakukan sejak 2012 tetapi tidak meningkatkan pemahaman dan batasan pengguna dalam bermedia sosial. Penelitian ini bertujuan meningkatkan pemahaman masyarakat terhadap literasi media sosial dan mampu mengendalikan interaksi yang berpotensi melanggar hukum. Metode penelitian menggunakan pendekatan kuantitatif dengan pengukuran tingkat pemahaman literasi media dilakukan dua kali, yaitu pada awal penelitian dan pada akhir penelitian. Penelitian ini digabungkan dengan treatment berupa : sosialisasi dan panduan praktis etika di media sosial. Hasil penelitian ini berupa peningkatan pemahaman terkait literasi media secara signifikan. Diperoleh hasil juga, responden kurang memahami etika dan hukum yang mengatur terkait penggunaan media sosial.
\end{abstract}

Kata kunci: Literasi Media, Literasi Media Sosial, Media Sosial 


\section{Pendahuluan}

Revolusi Industri 4.0 membawa perubahan yang signifikan dalam perkembangan media berbasis daring terutama media sosial. Sebagai alat berkomunikasi baik personal maupun grup, media sosial menjadi alat yang paling banyak digunakan oleh masyarakat saat ini. Sebuah penelitian dari We Are Social yang bekerjasama dengan Hootsuite memperoleh data bahwa sebanyak 132,7 juta orang di Indonesia menggunakan internet dan 130 juta orang aktif di media sosial (wearesocial.com, 2018). Dari hasil penelitian tersebut menunjukkan bahwa media sosial adalah alat yang paling dominan yang digunakan masyarakat untuk berkomunikasi daring.

Penelitian lain yang diungkapkan oleh UNESCO menyebutkan bahwa 4 dari 10 Orang di Indonesia aktif di media sosial. Peringkat tertinggi media sosial yang digunakan orang Indonesia yaitu Facebook sejumlah 3,3 juta orang dan whattssapp sejumlah 2.9 juta orang (kominfo.go.id, 2019). Hal ini semakin diperkuat dengan tingginya penggunaan gadget di Indonesia yang menempati urutan nomor 4 terbanyak di dunia (okezone.com, 2019).

Masyarakat yang terpapar media sosial tidak lagi yang berdomisili di kota-kota besar akan tetapi sudah merambah ke daerah-daerah. Hal ini ditengarai akibat dari terbukanya akses di segala bidang terutama kebutuhan akan informasi yang cepat dan berbasis daring. Dari banyaknya pengguna internet dan media sosial ini tentu membawa banyak pengaruh baik positif maupun negatif pada masyarakat daerah.

Dalam hal ini kabupaten Sleman merupakan salah satu daerah yang terpapar media sosial. Kabupaten yang berada di Daerah Istimewa Yogyakarta ini memiliki karakteristik secara sosial memiliki potensi masyarakat nomaden yang cukup besar. Hal ini terlihat dari banyaknya mahasiswa yang berada dan tinggal di daerah Sleman terkait dengan banyaknya kampus dan perguruan tinggi. Adapun kampus dan perguruan tinggi yang ada antara lain: Universitas Gadjah Mada, Universitas Islam Indonesia dan Universitas Atmajaya. Masyarakat nomaden yang memiliki karakteristik berpendidikan tinggi ini memberikan dampak terkait meluasnya penggunaan media sosial di kalangan masyarakat Sleman.

Meluasnya pengguna media sosial di Kabupaten Sleman ini perlu diimbangi dengan adanya pemahaman literasi media. Literasi media pada masyarakat dapat dilakukan dengan pendekatan komunikasi organisasi (organisational organisation). Dalam hal ini peneliti melakukan pendekatan komunikasi organisasi pada organisasi Pendidikan Kesejahteraan Keluarga (PKK) di daerah Sleman Yogyakarta.

Pemilihan organisasi PKK sebagai objek penelitian karena didasari atas pemahaman bahwa ibu sebagai pengasuh anak dan mengatur keluarga seharusnya memahami literasi media sosial. Pentingnya penelitian ini untuk penerapan model literasi media yang efektif dan signifikan pada pemahaman masyarakat atas literasi media sosial.

\section{Komunikasi Massa dan Media Sosial}


Media berkembang sangat pesat dengan adanya kemajuan teknologi yang mengiringinya. Perkembangan media ini terutama pada media massa yang berbasis daring (internet), salah satunya adalah media sosial. Media massa yang awalnya hanya terbagi atas media elektronik konvensional (tv dan radio) dan media cetak kini memiliki platform yang lebih unggul dengan adanya internet. Media massa berbasis internet tentu saja menjadi paling dominan penggunaannya dibandingkan dengan media massa konvensional.

Komunikasi dengan menggunakan media massa disebut sebagai komunikasi massa. Komunikasi massa sendiri seperti yang diungkapkan oleh Bittner merupakan penyampaian pesan melalui media massa pada sejumlah besar orang (dalam Rakhmat 1985 : 176). Hal ini diartikan bahwa komunikasi massa ini akan memberikan dampak pada masyarakat luas yang mengkonsumsi media massa. Padahal masyarakat yang mengkonsumsi media massa itu anonim dan tidak teridentifikasi secara personal.

Media sosial yang merupakan wujud terbaru dari media massa tentu tak jauh berbeda dampaknya kepada masyarakat luas, karena aksesbilitasnya juga pada banyak orang dan anonim. Media sosial sendiri menurut Kaplan dan Michael (2010) merupakan sekelompok aplikasi yang berbasis daring (internet) dan dibangun atas ideologi dan teknologi Web 2.0 yang memungkinkan adanya pertukaran konten yang dibuat oleh pengguna.

Pada mulanya, kemunculan Friendster pada tahun 2002 dianggap sebagai media sosial pertama kali yang didirikan oleh Jonathan Abrams. Akan tetapi dengan perkembangan internet yang ada, media sosial memiliki lebih banyak ragamnya seperti : LinkedIn, Flicker, Tumblr, Pinterest, BBM, Line, KakaoTalk, Path, Skype, Twitter, Instagram, Facebook, dan Whatsapp.

Dari banyaknya media sosial yang digunakan dapat dibagi dalam 6 kategori, antara lain (nasrullah $2015: 11$ ):

1. Jejaring sosial (Social Networking)

Merupakan media yang paling banyak digunakan dalah hubungan sosial dan komunikasi berbasis daring. Pengguna dalam membentuk jaringan pertemanannya sendiri dan saling berhubungan dengan berbagi pesan, gambar dan video. Jejaring sosial ini seperti : Path, Facebook, dan Instagram.

2. Blog

Blog biasanya berbentuk web pribadi yang isinya berupa keseharian, opini, pendapat ataupun hobi pengguna. Pengguna blog biasanya memeiliki domain tersendiri untuk alamat websitenya seperti : blogspot dan wordpress.

3. Micro-blogging

Tidak jauh berbeda dengan blog, akan tetapi ada pembatasan penulisan pendapat dan opini yang dapat kita temui di twitter.

4. Media Sharing

Biasa disebut juga sebagai media berbagi dimana pengguna dapat membagikan seluruh video, photo dan keseharian kepada masyarakat luas. Bentuk media sharing yang paling banyak digunakan adalah youtube. 
5. Social bookmarking

Merupakan media sosial yang dapat mengelola, menyimpan, dan mencari informasi berbasis daring. Salah satu yang banyak digunakan adalah LintasMe.

6. Media konten bersama

Menggabungkan beberapa konten dan fungsi media sosial yang ada. Hal ini dapat terlihat di wikipedia, semacam ensiklopedi berbasis daring yang biasanya berisi sejarah dan rujukan mengenai sebuah fenomena ataupun peristiwa.

\section{Literasi Media Sosial}

Kamus Besar Bahasa Indonesia memberikan definisi literasi sebagai kemampuan individu untuk mengolah informasi dan pengetahuan untuk kecakapan hidup. Hal ini menunjukkan bahwa untuk bisa mencapai derajat paham literasi, maka individu haruslah mampu memilih dan mengolah informasi mana saja yang baik dan tidak baik untuk dirinya.

Literasi media menurut Potter (2005) diartikan sebagai cara pandang yang digunakan dalam mengintepretasikan makna pesan yang diterima. Dalam hal ini pengguna harus memiliki kemampuan dalam memahami teks dan konteks sebuah pesan dalam komunikasi. Hal ini menuntut perilaku aktif pengguna untuk secara sadar memilah informasi mana saja yang menjadi kebutuhan dan berdampak positif pada dirinya.

Pengguna atau orang yang memiliki kemampuan literasi media menurut (Baran : 1999) memiliki beberapa karakter khusus, diantaranya :

1. Memahami bagaimana pembuatan berita di media

2. Menyadari terpaan media yang begitu besar pada masyarakat dan memberikan pengaruh pada gaya hidup, tingkah laku, dan nilai

3. Mampu mengintepretasikan pesan dalam upaya memperluas wawasan

4. Memiliki kepekaan pada konten media dan memahami kekuatan yang ada di dalamnya

5. Memahami kinerja industri media dengan memahami terkait kepemilikan, regulasi, dan finansialnya.

6. Menyadari bahwa media turut memberikan pengaruh dalam pengambilan keputusan

Pemahaman mengenai literasi media tersebut tidak hanya berlaku pada media konvensional (elektronik dan cetak) saja, melainkan juga pada media berbasis daring terutama media sosial. Media sosial sendiri memiliki banyak macam, fungsi, serta channel yang dapat dipilih sehingga membuat pengguna harus lebih cerdas dalam mengintepretasikan makna pesan yang ada di dalamnya. Penyebaran informasi di media sosial terjadi sangat cepat dan memerlukan intepretasi mendalam terkait dengan pornografi, ujaran kebencian, tindak pidana perdagangan orang, penipuan dalam jual beli secara online dan juga hoax. 
Menurut KBBI pornografi merupakan penggambaran tingkah laku secara erotis dengan lukisan atau tulisan untuk membangkitkan nafsu birahi. Objek pornografi dalam hal ini biasanya adalah perempuan, dan penikmat dari konten pornografi di media sosial biasanya laki-laki.

Tabel 1. Ragam Gerakan Literasi media

\begin{tabular}{|c|c|c|c|}
\hline Level & Tujuan & Sasaran & Aksi Konkret \\
\hline Regulasi & $\begin{array}{c}\text { Menghasilkan } \\
\text { perundang-undangan } \\
\text { dan regulasi yang } \\
\text { menjadi sistem media } \\
\text { massa yang sehat, } \\
\text { menyediakan payung } \\
\text { hukum bagi } \\
\text { pelanggaran terhadap } \\
\text { hak publik yang } \\
\text { dilakukan oleh media } \\
\text { massa. }\end{array}$ & $\begin{array}{c}\text { Lembaga legislatif, } \\
\text { pemerintah dan } \\
\text { organ-organnya, } \\
\text { lembaga hukum }\end{array}$ & $\begin{array}{c}\text { Melakukan advokasi } \\
\text { lewat pressure group } \\
\text { untuk membentuk } \\
\text { undang-undang, } \\
\text { regulasi, dan komisi- } \\
\text { komisi guna } \\
\text { mengawasi kinerja } \\
\text { dan sistem media } \\
\text { massa; } \\
\text { mengupayakan } \\
\text { masuknya materi } \\
\text { media literacy dalam } \\
\text { kurikulum nasional, } \\
\text { dll. }\end{array}$ \\
\hline $\begin{array}{l}\text { Produksi } \\
\text { Teks/ } \\
\text { Wacana }\end{array}$ & $\begin{array}{c}\text { Memberi perspektif } \\
\text { media literacy pada } \\
\text { pekerja media, lembaga, } \\
\text { dan owner; mengubah } \\
\text { kebijakan media agar } \\
\text { lebih berpihak pada } \\
\text { upaya pencerdasan } \\
\text { khalayak melalui } \\
\text { program-program yang } \\
\text { berkualitas; membantu } \\
\text { mengonstruksi pasar } \\
\text { dan sistem media massa } \\
\text { yang sehat demi } \\
\text { kepentingan bersama }\end{array}$ & $\begin{array}{l}\text { Pekerja media, owner } \\
\text { atau pemilik media, } \\
\text { penentu kebijakan } \\
\text { dalam institusi media } \\
\text { Perguruan tinggi atau } \\
\text { lembaga pendidikan } \\
\text { yang memiliki studi } \\
\text { komunikasi massa. }\end{array}$ & $\begin{array}{l}\text { Melakukan advokasi } \\
\text { pada penentu } \\
\text { kebijakan atau owner } \\
\text { guna mengubah } \\
\text { kebijakan seputar } \\
\text { media sehingga lebih } \\
\text { berpihak pada } \\
\text { kepentingan publik; } \\
\text { melakukan pelatihan } \\
\text { pada pekerja media } \\
\text { untuk menghasilkan } \\
\text { program yang } \\
\text { berkualitas; } \\
\text { mengupayakan } \\
\text { masuknya materi } \\
\text { media literacy dalam } \\
\text { kurikulum nasional }\end{array}$ \\
\hline Audience & $\begin{array}{c}\text { Memberi penguatan } \\
\text { pada khalayak agar } \\
\text { cerdas, bijak, berdaya, } \\
\text { ketika berhadapan } \\
\text { dengan media massa }\end{array}$ & $\begin{array}{l}\text { Masyarakat dalam } \\
\text { berbagai kelas dan } \\
\text { level, siswa sekolah } \\
\text { dalam berbagai } \\
\text { tingkat pendidikan, } \\
\text { perempuan, dll }\end{array}$ & $\begin{array}{c}\text { Mengampanyekan } \\
\text { gerakan media } \\
\text { literacy; melakukan } \\
\text { pelatihan media } \\
\text { literacy pada elemen- } \\
\text { elemen masyarakat. }\end{array}$ \\
\hline
\end{tabular}

Sumber: Astuti, Santi Indra , 2007 
Penelitian ini menggunakan level yang terakhir yaitu memperkenalkan dan mengkampanyekan gerakan literasi media terkait dengan media sosial. Peneliti melakukan kampanye literasi media sosial melalui seminar yang dihadiri oleh anggota organisasi PKK.

\section{Metode Penelitian}

Penelitian ini menggunakan purposive sampling dengan pendekatan kuantitatif yang bertujuan untuk mendeskripsikan sebuah fenomena kemudian hasilnya dapat digeneralisasi (Kriyantono, 2006). Penelitian ini menggunakan kuesioner sebagai instrumen dalam pengukuran. Analisis data dilakukan dengan entry data dan validasi data kemudian peneliti memasukkannya dalam sistem SPSS 21 untuk dihitung prosentasenya. Tahap selanjutnya, hasil tersebut di intepretasikan serta dianalisis. literasi.

Penelitian ini menggunakan 3 tahapan untuk mendapatkan hasil pengukuran tingkat

1. Pengukuran tingkat literasi media sosial tahap pertama menggunakan kuesioner tertutup dengan skala 1-5 dan diberikan kepada responden pada awal penelitian

2. Responden diberikan informasi terkait dengan literasi media sosial melalui pertemuan tatap muka, ceramah, dan leaflet

3. Pengukuran tingkat literasi media sosial tahap kedua menggunakan kuesioner tertutup yang sama seperti awal penelitian dengan skala 1-5

\section{Hasil dan Pembahasan}

Seluruh responden dalam penelitian ini berjenis kelamin perempuan dengan rentang usia 20 - 60 tahun. Sejumlah $68 \%$ pendidikan terakhir responden yaitu SLTA dan $12 \%$ nya lulusan SLTP. Dalam hal pekerjaan sejumlah $74 \%$ responden bekerja sebagai ibu rumah tangga.

\section{Media Sosial, Literasi Media, dan Literasi Media Sosial}

Istilah literasi media kini tidak hanya dipahami dan diketahui oleh kalangan pendidik dan akademisi saja, melainkan juga masyarakat awam. Hal ini terbukti bahwa responden cukup memahami istilah media sosial, literasi media dan literasi media sosial. Setelah responden mendapatkan informasi terkait dengan literasi media sosial maka pemahamannya juga meningkat meningkat. Menjadi perhatian yaitu adanya peningkatan signifikan dari pengukuran tahap 1 ke pengukuran tahap 2 yang rata-rata meningkat sejumlah $19,76 \%$.

Grafik 1. Pemahaman Media Sosial, Literasi Media, Literasi media Sosial 


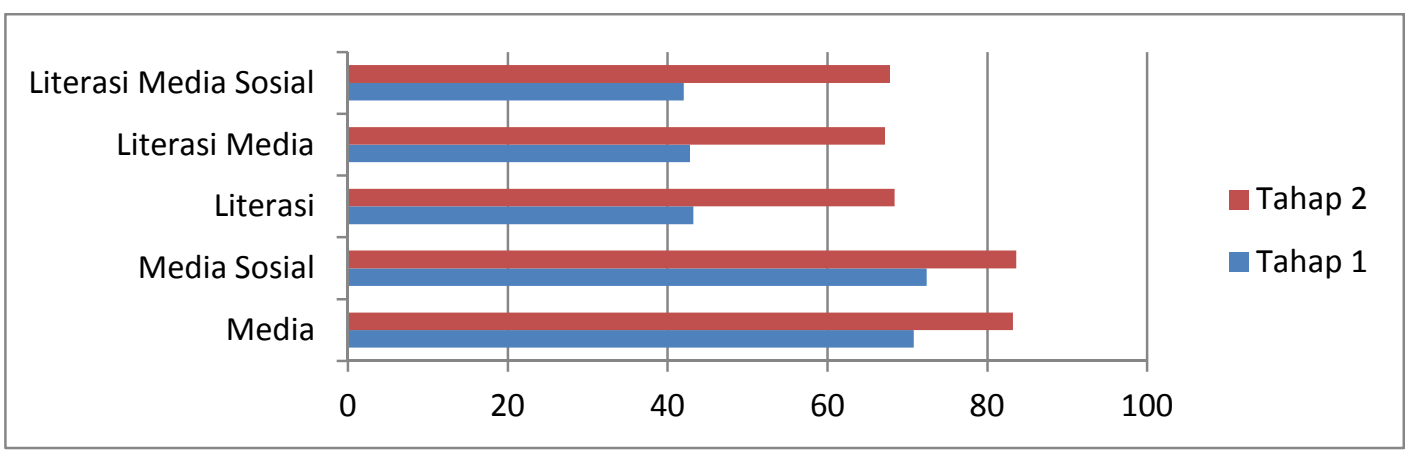

Sumber : Diolah dari data primer

Melihat hasil peningkatan dari pemahaman tersebut menunjukkan bahwa istilah media sosial atau medsos sudah menjadi konsumsi umum masyarakat. Istilah lain yaitu literasi media juga tidak hanya terbatas pada masyarakat berpendidikan tinggi saja, melainkan juga masyarakat secara umum. Istilah literasi media sosial juga sudah familiar di kalangan masyarakat.

Sebelum adanya smartphone dan media sosial, televisi menjadi bagian yang tak terpisahkan dari masyarakat. Bahkan televisi disebut-sebut telah menjadi anggota keluarga, karena selalu digunakan ketika jam-jam bersama keluarga. Kenyataannya, saat ini media sosial berpotensi menjadi salah satu media mainstream selain televisi dan radio. Bahkan smartphone dan media sosial bukan hanya bagian dari keluarga, tetapi menjadi bagian dari individu penggunanya.

Seperti yang diungkapkan oleh Rahardo dalam Kasali bahwa media sosial adalah media jejaring social yang memungkinkan seseorang dapat berbicara, berpartisipasi, berbagi, dan menciptakan jejaring secara online. Kasali sendiri mengungkapkan dalam interaksinya para pelaku saling membentuk opini, mengekspresikan diri, mencari kawan, saling memberikan informasi kejadian seharihari, merekomendasikan produk atau jasa yang mereka gunakan, dan lain sebagainya (Kasali, 2011:14-38).

Keunggulan media sosial terkait dengan cepatnya feedback membuat masyarakat akan dengan mudah menyampaikan informasi timbal balik atas informasi yang telah diterima. Jika dulu pemahaman atas media sosial sebagai 'dunia maya' atau dunia yang tidak sebenarnya, kini media sosial merupakan platform baru dunia sebenarnya dengan basis digital. Hal ini sejalan yang disampaikan Zubair bahwa komunikasi di dunia nyata telah berpindah platform dalam dunia maya. Kemudian eksistensi manusia juga ditentukan dengan kepemilikan akun di media sosial (Zubair, 2010)

\section{Penggunaan Media Sosial}

Penggunaan media sosial di Indonesia cukup beragam, akan tetapi dalam penelitian ini menunjukkan bahwa sebanyak 58\% memahami tentang penggunaan facebook, 51,6\% memahami penggunaan instagram, dan sejumlah 68,8\% memahami penggunaan whatsapp. Ketika diberikan pemahaman dan informasi terkait dengan 
penggunaan media sosial, maka pemahaman responden rata-rata meningkat menjadi $14,8 \%$

\section{Grafik 2. Pemahaman Penggunaan Media Sosial}

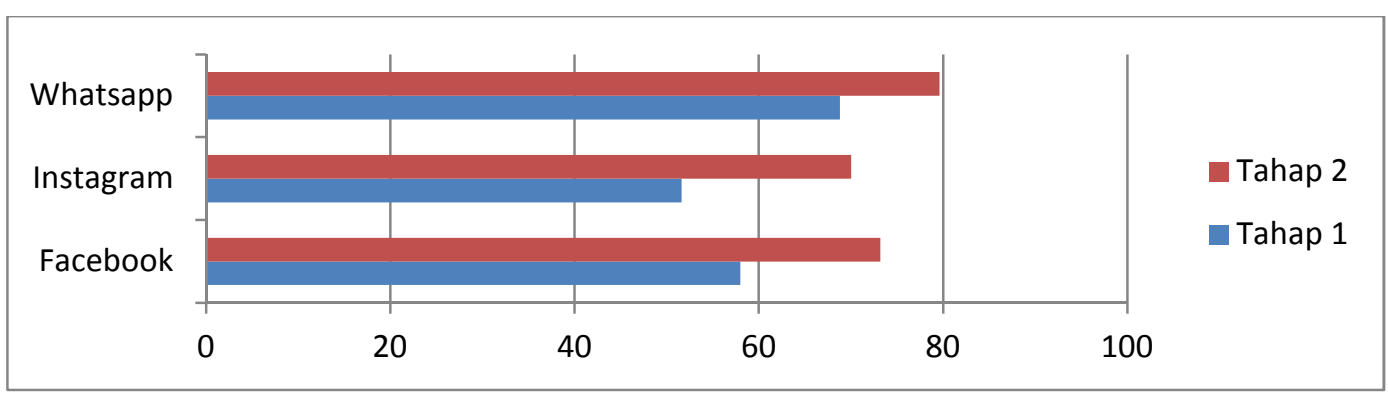

Sumber : Diolah dari data Primer

Menjadi menarik ketika aplikasi whatssapp menjadi media sosial paling dipahami oleh responden. Dalam penelitian ini juga menunjukkan bahwa lebih dari separuh responden menggunakan whatsaap sebagai alat berkomunikasi. Aplikasi Whatsapp menyuguhkan sebuah konsep komunikasi secara personal maupun dalam kelompok. Komunikasi yang terjalin dapat berupa pertukaran pesan chatting, video, gambar, dan suara. Aplikasi ini juga memiliki fitur untuk menggunggah status, menelepon, dan video call.

Tabel 2. Jenis Komunikasi dan pertukaran di Media Sosial

\begin{tabular}{|c|c|c|c|c|c|c|c|c|}
\hline \multirow{3}{*}{ Aplikasi } & \multicolumn{2}{|c|}{ Jenis Komunikasi } & \multicolumn{5}{|c|}{ Jenis Pertukaran Pesan } & \multirow{3}{*}{$\begin{array}{c}\text { Pembarua } \\
\text { n Status }\end{array}$} \\
\hline & \multirow{2}{*}{$\begin{array}{c}\text { Persona } \\
1\end{array}$} & \multirow[b]{2}{*}{$\begin{array}{c}\text { Kelompo } \\
\text { k }\end{array}$} & \multicolumn{3}{|c|}{ Chatting } & \multirow{2}{*}{$\begin{array}{c}\text { Vide } \\
\text { o } \\
\text { Call }\end{array}$} & \multirow{2}{*}{$\begin{array}{l}\text { Voic } \\
\mathrm{e} \\
\text { Call }\end{array}$} & \\
\hline & & & $\begin{array}{c}\text { Tek } \\
\text { S }\end{array}$ & $\underset{r}{\text { Gamba }}$ & $\begin{array}{c}\text { Vide } \\
\text { o }\end{array}$ & & & \\
\hline $\begin{array}{c}\text { Whatssap } \\
\text { p }\end{array}$ & $\sqrt{ }$ & $\sqrt{ }$ & $\sqrt{ }$ & $\sqrt{ }$ & $\sqrt{ }$ & $\sqrt{ }$ & $\sqrt{ }$ & $\sqrt{ }$ \\
\hline Facebook & $\sqrt{ }$ & $\sqrt{ }$ & $\sqrt{ }$ & $\sqrt{ }$ & - & - & - & $\sqrt{ }$ \\
\hline Instagram & $\sqrt{ }$ & $\sqrt{ }$ & $\sqrt{ }$ & $\sqrt{ }$ & $\sqrt{ }$ & - & - & $\sqrt{ }$ \\
\hline
\end{tabular}

\section{Sumber : Hasil olahan pribadi}

Dari tabel di atas menunjukkan bahwa aplikasi whatsapp memiliki fitur yang paling bervariatif sehingga hal ini bepotensi untuk menjadikannya aplikasi yang paling diminati masyarakat. Saat ini penggunaan aplikasi sebagai media berkomunikasi cukup efektif dikarenakan platform yang digunakan lebih beragam dan membuat masyarakat bebas memilih mana saja yang sesuai dengan kebutuhannya.

Walaupun Whatsapp memiliki pengguna yang cukup banyak dalam penelitian ini tetapi secara global Facebook yang mempati peringkat tertinggi. Pengguna Facebook 
secara global memiliki 2,2 milyar pengguna, Instagram sejumlah 1 milyar pengguna, dan Whatsapp sejumlah 1,5 milyar pengguna (statista.com, 2018).

\section{Etika Menggunakan Media Sosial}

Dalam literasi media sosial, pengguna diharapkan memahami adanya etika dalam menggunakan media sosial. Dalam penelitian ini terdapat rata-rata peningkatan pemahaman responden terkait dengan adanya pornografi dan ujaran kebencian sejumlah $9,4 \%$.

Grafik 3. Pemahaman Etika Penggunaan Media Sosial

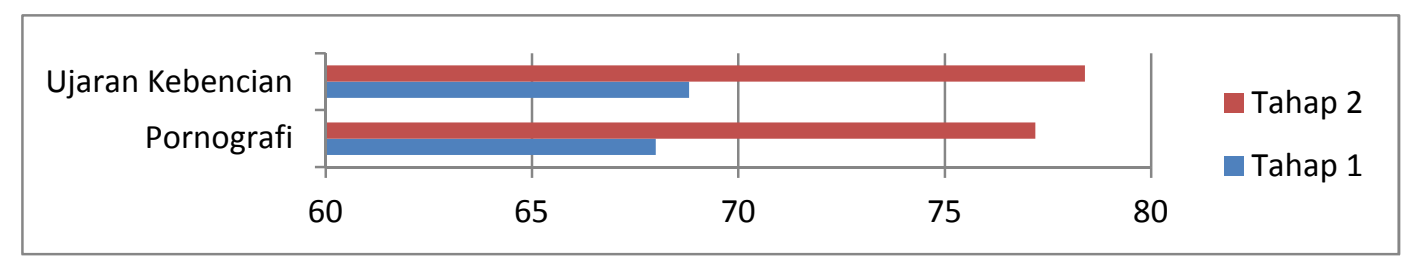

Sumber : Diolah dari data primer

Pemahaman responden pada pengukuran tahap 1 yang hanya sejumlah $68 \%$ menunjukkan bahwa responden belum memahami dan membedakan antara konten pornografi dan konten umum. Padahal dalam penelitian yang dilakukan Rachmaniar menunjukkan bahwa masyarakat dapat mengakses pornografi di internet dan media sosial secara tidak sengaja karena adanya persebaran informasi yang tidak terbatas (Rachmaniar dkk, 2018). Hal di atas menunjukkan bahwa responden dalam penelitian ini berpotensi untuk mendapatkan informasi terkait pornografi tetapi tidak mengetahui bahwa sejatinya itu konten pornografi.

Pornografi sendiri dalam Undang - Undang RI Nomor 1 Ayat 1 dijelaskan sebagai gambar, sketsa, ilustrasi, foto, tulisan, suara, bunyi, gambar bergerak, animasi, kartun, percakapan, gerak tubuh, atau bentuk pesan lainnya melalui berbagai bentuk media komunikasi dan/atau pertunjukan di muka umum, yang memuat kecabulan atau eksploitasi yang melanggar norma kesusilaan dalam masyarakat (Kementerian Hukun dan Hak Azasi Manusia, 2008).

Etika lain dalam menggunakan media sosial, sebaiknya pengguna menghindari menyebarluaskan konten ujaran kebencian. Ujaran kebencian sendiri merupakan upaya provokasi atau mendorong orang lain untuk tidak menyukai seseorang atau kelompok. Upaya provokasi yang berisi ujaran kebencian di media sosial ini dapat memberikan pengaruh berupa perubahan sikap seseorang baik itu pada pengguna yang terpapar ataupun pada orang yang menyebarkannya (Sri Marwati, 2018).

Kebebasan berpendapat yang diatur dalam Pasal 28 UUD 1945 tidak kemudian serta merta menjadi tolok ukur bebasnya berperilaku dan menyampaikan gagasan di media sosial. Okta Wibowo menyampaikan bahwa perilaku menggunakan media sosial sedang tidak diawasi secara langsung tetapi pengawasannya lebih kepada pengguna 
media sosial untuk mendisiplinkan diri melalui akun media sosialnya (Okta Wibowo, 2019).

\section{Manfaat dan Bahaya Media sosial}

Media sosial sebagai salah satu media yang paling digemari tentu saja memiliki daya tarik yang lebih menonjol dibandingkan dengan media konvensional lainnya seperti televisi dan radio. Dengan kekuatan akses internet membuat sangat mudah terkoneksi dengan seluruh dunia dan penyebaran informasi menjadi sangat cepat.

Dalam hal ini, responden yang sebelumnya memahami bahwa media sosial memiliki akses ke seluruh dunia dan persebaran informasinya cepat rata-rata pada pengukuran tahap 1 sebesar $77,6 \%$ meningkat menjadi rata-rata $81,4 \%$ pada pengukuran tahap 2. Hal ini menunjukkan bahwa walaupun pada awalnya responden cukup memahami dengan baik manfaat media sosial, dengan adanya treatmen dari peneliti pemahaman responden semakin meningkat.

Grafik 4. Pemahaman Manfaat Media Sosial

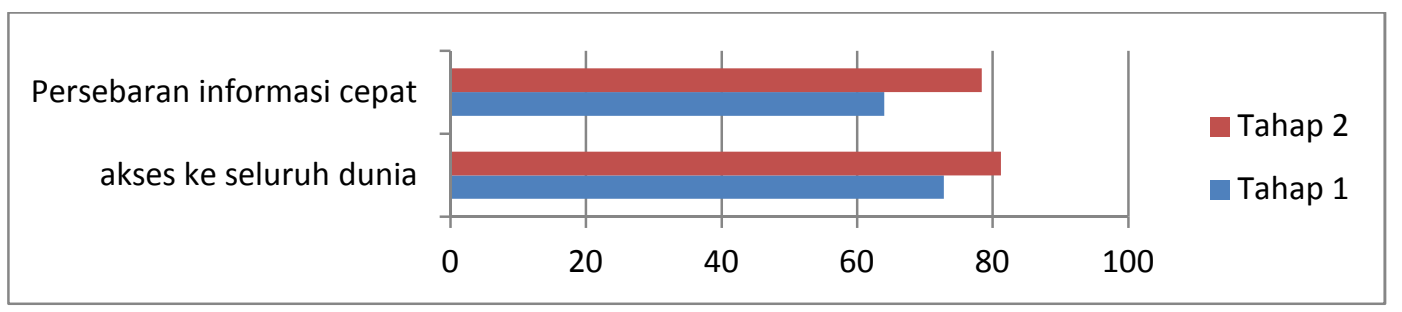

Sumber : Diolah dari data primer

Dampak media sosial pada masyarakat tidak selamanya positif dan bermanfaat, akan tetapi terdapat juga sisi negatif dari interaksi manusia di media sosial. Terdapat beberapa hal yang menjadi indikator media sosial berdampak negatif seperti : kejahatan di media sosial, perdagangan manusia, penipuan jual beli online, dan hoax.

Grafik 5. Pemahaman Bahaya Media Sosial

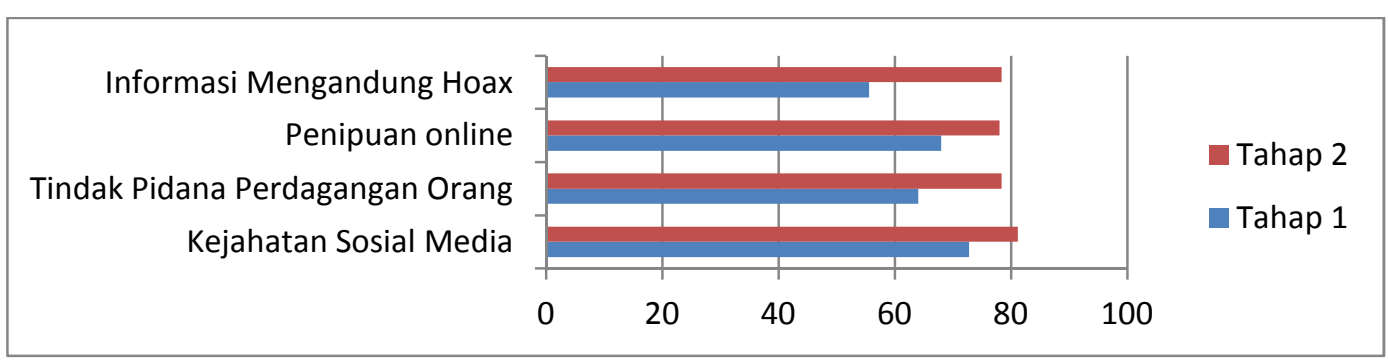

Sumber : Diolah dari data primer

Dari Grafik di atas terlihat bahwa lebih dari separuh responden memahami bahwa media sosial berpotensi sebagai alat untuk melakukan kejahatan. Kejahatan di media sosial ini bentuknya bermacam - macam, seperti : tindak pidana perdagangan orang (TPPO), penipuan online, dan juga informasi mengandung hoax. Rusmana 
menjelaskan bahwa media sosial memiliki kekuatan dalam menyajikan pesan verbal dan nonverbal serta interaktivitas yang tinggi. Kekuatan ini dapat membuat persepsi pengguna bahwa dia mengetahui seluruh peristiwa yang disampaikan komunikannya dan mempercayai bahwa semuanya benar (Rusmana, 2015).

Kasus - Kasus TPPO banyak berkaitan dengan prostitusi online, bahkan belum lama terdapat beberapa artis yang terlibat. Dalam kasus prostitusi online artis tersebut, media sosial digunakan sebagai alat untuk menawarkan, membuat kesepakatan, dan bertransaksi (tribunnews.com,2019).

Kejahatan penipuan online juga menjadi potensi yang mengancam pengguna media sosial. Penipuan sendiri merupakan tindakan seseorang atau sekelompok orang dengan membuat kesan bahwa sesuatu itu benar agar orang lain percaya, walaupun sejatinya palsu (Anwar, 1979:16).

Penyebaran fake news atau biasa disebut hoax atau berita bohong menjadi salah satu fenomena yang terjadi pada penggunaan media sosial. Terpaan fake news atau hoax menyasar pada seluruh lapisan masyarakat, responden pada penelitian ini. Terutama saat pengukuran penelitian ini dilakukan beberapa bulan sebelum pemilu 2019, bahwa sekita 997 hoax tersebar di media sosial dan rata-rata bertemakan politik (voaindonesia.com, 2019).

\section{Mensikapi Hoax}

Terdapat beberapa kecakapan yang harus dikuasai oleh pengguna media sosial dalam mengidentifikasi hoax dan informasi kebenaran. Ada tiga hal yang diukur dalam kecakapan ini, antara lain: membaca detil informasi, memahami isi informasi dan mengecek kebenaran informasi.

Grafik 6. Pemahaman Mensikapi Hoax

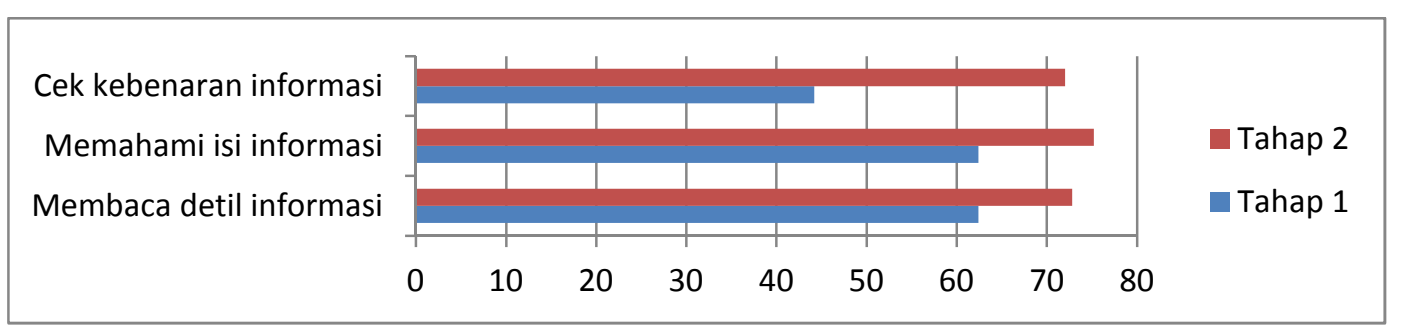

Sumber : Diolah dari data primer

Kemampuan responden untuk berupaya membaca dan memahami detil informasi yang tersebar di media sosial cukup tinggi dibandingkan dengan mengecek kembali kebenaran informasi. Ini menunjukkan adanya potensi untuk menyebarluaskan hoax dari responden kepada orang lain. Ini merupakan salah satu dampak dari penggunaan media sosial, pengguna tidak memiliki sikap kritis dalam merespon sebuah informasi. Bahkan kemudian pengguna media sosial membagikan informasi hoax tersebut secara sukarela (Herawati, 2016). 
Pengukuran ketiga hal terkait penyikapan yang seharusnya responden lakukan terhadap pesan di media sosial sejalan dengan yang disampaikan Ariesta bahwa, kecapakan pertama adalah harus berhati-hati dengan judul berita ataupun informasi yang provokatif. Kedua, pengguna media sosial harus teliti dalam melihat suber berita. Perlu diketahui siapakah pembuat pesan dan kemudian kapan dan dimana informasi itu diperoleh. Ketiga, pengguna harus memeriksa keaslian pesan/informasi. Pengguna diharapkan dapat melihat sebuah pesan/informasi tersebut berisikan fakta yang relevan dengan data yang mencukupi. Pengguna media sosial diharapkan tidak mudah terprovokasi dengan pesan/informasi yang menipu (Ariesta dalam Juditha, 2018)

\section{Kontrol Pemerintah melalui Kominfo}

Penggunaan media sosial di Indonesia sebenarnya diatur oleh pemerintah dengan kebijakan - kebijakan yang dilakukan oleh Kementrian Komunikasi dan Informasi (Kemenkominfo). Terdapat beberapa hal yang menjadi kebijakan Kemenkominfo antara lain Undang Undang Informasi dan Transaksi Elektronik (UU ITE), pemblokiran akun media sosial, dan pemblokiran aplikasi.

Grafik 7. Pemahaman Peraturan Penggunaan Media Sosial

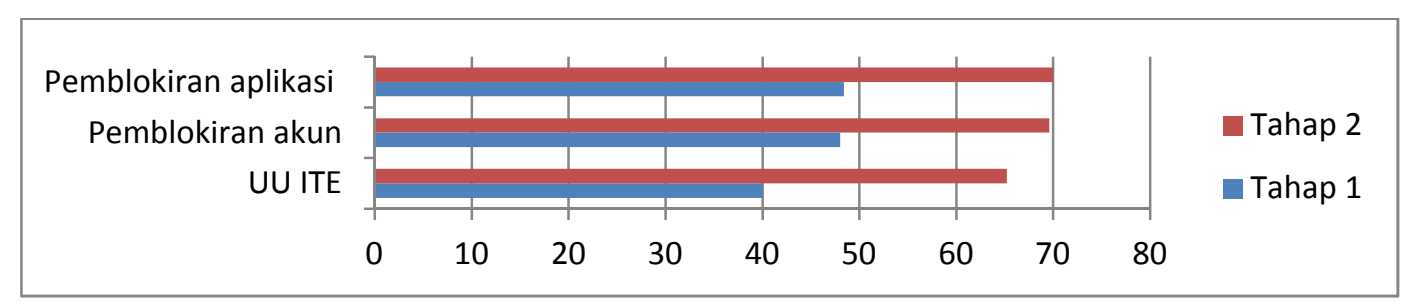

Sumber : Diolah dari data primer

UU ITE sendiri berisikan informasi dan transaksi eletronik juga peraturan apa saja yang tidak boleh dilakukan saat menggunakan internet. Walapun sudah disahkan sejak tahun 2012 tetapi ternyata sosialisasi dan informasi terkait UU ITE belum dipahami sebagian masyarakat. Hal ini terlihat pada pengukuran tahap 1 pemahaman responden terhadap kontrol pemerintah terkait dengan penggunaan internet dan media sosial kurang dari 50\%. Ini menunjukkan bahwa responden cenderung tidak mengetahui bahwa perilaku di internet dan media sosial ada atusan dan batasannya.

Padahal pemerintah telah melakukan beberapa upaya seperti : pemblokiran akun media sosial ataupun pemblokiran aplikasi media sosial. Pemerintah dalam hal ini Kominfo bahkan telah memblokir lebih dari 960 ribu akun media sosial yang memiliki konten negatif melanggar UU ITE pada tahun 2018 (Suara.com, 2019). Begitupun aplikasi media sosial, seperti aplikasi Bigo Live yang sempat diblokir karena banyaknya konten negatif yang diunggah penggunanya. Akan tetapi, pada tahun 2017 aplikasi Bigo Live sudah dicabut pemblokirannya dan dapat diakses kembali oleh penggunanya (kompas.com,2017).

Walaupun UU ITE telah ditetapkan oleh pemerintah, akan tetapi penegakan hukumnya masih dianggap kurang. Dari hasil penelitian yang dilakukan Suyanto Sidik 
juga menjelaskan bahwa teknologi informasi terkait internet ini memiliki dampak negatif yang dapat merugikan banyak pihak. Hal itu terjadi akibat belum jelasnya hukum yang mengatur penggunaan teknologi informasi juga lemahnya aturan tentang jaminan keamanan dan kerahasiaan informasi (Suyanto sidik, 2013).

\section{KESIMPULAN}

Penelitian ini menunjukkan bahwa model peningkatan literasi media yang telah dilaksanakan peneliti mampu meningkatkan secara signifikan pemahaman responden mengenai literasi media. Terdapat tiga aplikasi yang paling banyak digunakan masyarakat antara lain: whatsapp, facebook, dan instagram. Tetapi pada penggunaannya, masyarakat kurang memahami adanya etika dalam menggunakan media sosial, terutama terkait dengan konten pornografi. Masyarakat belum dapat membedakan secara jelas antara konten pornografi dengan konten umum.

Masyarakat sudah memahami bahwa media sosial memiliki banyak sekali manfaat tetatpi juga terdapat bahaya yang menyertainya. Salah satu bahaya yang paling berpotensi diterima masyarakat adalah berita bohong atau hoax. Masyarakat cenderung kurang bisa memahami antara berita hoax ataupun berita kebenaran dan hal ini bepotensi membuat masyarakat menyebarluaskannya secara tidak sadar. Masyarakat memahami bahwa kontrol pemerintah melalui UU ITE dan juga pemblokiran aplikasi serta akun media sosial memberikan batasan - batasan terkait penggunaan sosial media.

Penelitian ini merekomendasikan untuk pengadaan pelatiham, sosialisasi, workshop dalam upaya peningkatan literasi media sosial. Peningkatan literasi ini terutama untuk ibu rumah tangga sebagai pendidik dan juga kontrol terhadap media sosial yang digunakan anak-anak di rumah.

\section{DAFTAR PUSTAKA}

Anwar, Moch, (1979). Hukum Pidana Bagian Khusus (KUHP II). Bandung : Percetakan Offset Alumni

Astuti, Santi Indra (2007). Media Literacy : Memerdekakan Khalayak dari Kapitalisme. Jurnal ISSUE (ISKI Bandung) Vol 1 No 1

Baran, Stanley J (1999). Introduction to Mass Communication, Media Literacy and Culture. California: Mayfield Publishing Company

Herawati, Dewi Maria (2016). Penyebaran Hoax dan Hate Speech sebagai Representasi Kebebasan Berpendapat, Jurnal PROMEDIA, Volume II No 2 Tahun 2016

Juditha, Christiany (2018). Interaksi Komunikasi Hoax di Media Sosial serta Antisipasinya. Jurnal PEKOMMAS Volume 3 Nomor 1, April 2018 
Kaplan, Andreas M \& Haenlein Michaes (2010). Users of the World, Unite! The Challenges and Opportunities of Social Media, Business Horizons, Vol. 53 Issue 1,2010

Kasali, Renald (2011). Cracking Zone. Jakarta: Gramedia Pustaka Utama

Marwati, Sri (2018). Jurnal TOLERANSI : Media Komunikasi Umar Beragama Volume 10 No 1, Januari - Juni 2018

Nasrullah, Rulli (2015). Media Sosial : Perspektif Komunikasi, Budaya, dan Sosioteknologi. Bandung : Simbiosa Rekatama Media. (hal 11)

Okta Wibowo, Tangguh (2018). Konstruksi Ujaran Kebencian melalui Status Media Sosial. CHANNEL Jurnal Komunikasi, Volume 6 Nomor 2, Okotober 2018

Potter, James (2005). Media Literacy. Thousands Oak : Sage Publication

Rachmaniar, dkk (2018). Perilaku Penggunaan Smartphone dan Akses Pornografi di Kalangan Remaja Perempuan. Jurnal Komunikasi GLOBLAL, Volume 7 Nomor 1 Tahun 2018

Rakhmat, Jalaluddin (1985). Psikologi Komunikasi. Bandung : Remadja Karya

Rusmana, Agus (2015). Penipuan dalam Interaksi melalui Media Sosial. Jurnal Kajian Informasi dan Keperpustakaan, Vol 3 No 2, Desember 2015

Sidik, Suyanto (2013). Dampak Undang-Undang Informasi dan Transaksi Elektronik (UU ITE) terhadap Perubahan Hukum dan Sosial dalam Masyarakat. Jurnal Ilmiah WIDYA, Volume 1 Nomor 1 Tahun 2013

Zubair, Agustina (2010). Fenomena Facebook : Keterlibatan Teknologi Komunikasi dalam Perkembangan Komunikasi Manusia, Jurnal ASPIKOM, vol. 1 : Nomor 1, Juli 2010

\section{Sumber Lain}

Data Asosiasi Pengguna Jasa Internet Indonesia (APJII) pada tahun 2017

Kominfo.go.id (30 Agustus 2018). Angka Penggunaan Media Sosial Orang Indonesia Tinggi Potensi Konflik juga Amat Besar. https://kominfo.go.id/content/detail/14136/angka-penggunaan-media-sosialorang-indonesia-tinggi-potensi-konflik-juga-amat-besar/0/sorotan_media diakses 25 januari 2019

Kompas.com (13 Januari 2017). Hari Ini Kemenkominfo Cabut Blokir Bigo Live. https://tekno.kompas.com/read/2017/01/13/17235937/hari.ini.kemenkominfo.cabu t.blokir.bigo.live diakses 30 mei 2019

Okezone.com (17 Februari 2018). Indonesia Pengguna Samsrtphone ke-4 Dunia Begini Tekad Menperin Dongkrak Industri Telematika https://economy.okezone.com/ 
read /2018 /02/17/320/1860752/indonesia-pengguna-smartphone-ke-4-duniabegini-tekad-menperin-dongkrak-industri-telematika Diakses 25 januari 2019

Statista.com . Indonesia Social Network Penetration. https://www.statista.com/statistics/284437/indonesia-social-network-penetration/ diakses Mei 2019

Suara.com (20 Maret 2019). Kominfo Blokir 961.456 Akun Media Sosial Sepanjang 2018. https:/www.suara.com/tekno/2019/03/20/130846/kominfo-blokir-961456akun-media-sosial-sepanjang-2018 Diakses 30 mei 2019

Tibunnews.com (06 Januari 2019). Terungkap Cara Transaksi Prostitusi Online yang Libatkan Vanessa Anggel dan Avriella Shaqqila http://batam.tribunnews.com/2019/01/06/terungkap-cara-transaksi-prostitusionline-yang-libatkan-vanessa-angel-dan-avriellia-shaqqila Diakses 30 Mei 2019

Voaindonesia.com (18 Maret 2019). Hoax Makin Merajalela Jelang Pemilu https://www.voaindonesia.com/a/hoax-makin-merajalela-jelang pemilu/4835646.html

Wearesocial.com . Global Digital Report 2018. https://wearesocial.com/blog/2018/01/global-digital-report-2018 Diakses 25 Januari 2019 